\title{
グラウンドアンカーによるケーソン式防波堤 の滑動防止工法に関する水理実験 HYDRAULIC MODEL EXPERIMENTS ON SLIDING STABILITY OF CAISSON BREAKWATER WITH GROUND ANCHOR FOR REINFORCEMENT
}

\author{
吉田誠 1 ・清宮理 $2 \cdot$ 田代聡一 $3 \cdot$ 合田和哉 4 ・竹家宏治 5 \\ Makoto YOSHIDA, Osamu KIYOMIYA, Soichi TASHIRO, Kazuya GOUDA and Koji TAKEYA \\ 1正会員 修(工） 五洋建設株式会社 技術研究所（３329-2746 杤木県那須塩原市四区町1534-1） \\ 2 フェロー 工博 早稲田大学教授 理工学術院創造理工学部社会環境工学科 \\ （广169-8555 東京都新宿区大久保3-4-1) \\ 3正会員＼cjkstart農修＼cjkstart東亜建設工業株式会社土木事業本部 \\ （テ163-1031 東京都新宿区西新宿3-7-1 新宿パークタワー31F） \\ 4正会員＼cjkstart博(工) 東洋建設株式会社 土木事業本部 \\ （テ135-0064 東京都江東区青海2-4-24 青海フロンティアビル） \\ 5 正会員 株式会社エスイー 営業統轄本部 \\ （テ160-0023 東京都新宿区西新宿6-3-1 新宿アイランドウイング）
}

\begin{abstract}
The rise of sea levels and the increase of wave forces which has been caused by global warming will cause the failure of breakwaters. The ground anchor for reinforcement is proposed as an anti-sliding method of caisson breakwaters. In this study, we conducted hydraulic model experiments with a scale of 1 to 30 model in order to investigate the sliding stability of caisson breakwaters with the ground anchor for reinforcement against wave forces. The results show that the caisson breakwater with the ground anchor for reinforcement increases the sliding resistance and reduces the sliding distance, and the larger the initial tension of the anchor is, the more effective as an anti-sliding method.
\end{abstract}

Key Words : Ground anchor, Caisson breakwater, Wave force, Sliding stability, Rubble mound, Hydraulic model experiment

\section{1.はじめに}

人間活動に伴う温室効果ガス濃度の増大に起因す る地球温暖化は気象・海象の変化を引き起こし, 今 後, 自然災害の増加などが懸念されている。 ICPP(Intergovernmental Panel on Climate Change)のレ ポートによると, $\mathrm{CO}_{2}$ 排出量の最も多いシナリオで は，100年後の世界の平均気温は約4度上昇すると予 測されている．気温上昇による地球温暖化は，海面 上昇や台風の巨大化による水深の増加, 波力増大な ぞを引き起こし，防波堤の安定性や機能が損なわれ る可能性が指摘されており ${ }^{1)}$, 防波堤の滑動防止対 策などが必要とされている。わが国で多く採用され ているケーソン式防波堤の滑動防止対策についてみ ると, 被災後復旧時の対策として, ケーソン幅の拡 幅や裏込材によるカウンターの設置などの事例があ る.

一方，グラウンドアンカーによる滑動防止対策が
提案されている. これは, ケーソンと直下の原地盤 の間にアンカーを設置し，アンカーに初期緊張力を 導入してケーソン底面の摩擦力を増加させることに より, ケーソンの滑動安全率の向上, 滑動量の低減 を図るとともに，ケーソンの流失や転倒を防止する 工法である。しかし，アンカーによる滑動防止効果 は十分には明らかにされていない。本研究では, ア ンカーで補強したケーソン式防波堤の水理実験を実 施し，アンカーによる滑動防止効果に関する基礎的 な検討を行った。

\section{2. アンカーによる滑動防止対策エ法の概要}

ケーソン式防波堤にアンカーによる滑動防止対策 工法を適用した場合の概念を図-1に示す．図-1では ケーソン1函あたりアンカー3本を設置する例を示し ている. アンカーは, ケーソンの幅方向の中心位置 
に中詰砂の中を傾角 $90^{\circ}$ で配置し，アンカー頭部は 上部工天端に固定し，アンカー体は原地盤に定着す ることを想定している. アンカーの施工は, 施工機 械が比較的小型であるため, ケーソン上部工天端か ら実施することを想定している。本工法は，アン カーに初期緊張力を導入することで, ケーソン底面 の摩擦抵抗力を増加させケーソンの滑動安全率の向 上や滑動量の低減を図る工法である。ささらに, 想定 を超える波力が作用した場合にもアンカーが係留索 と同様の役割を果たす可能性があり，ケーソンの流 失や転倒を防止することで防波堤機能の確保や早急 な復旧が期待できる.

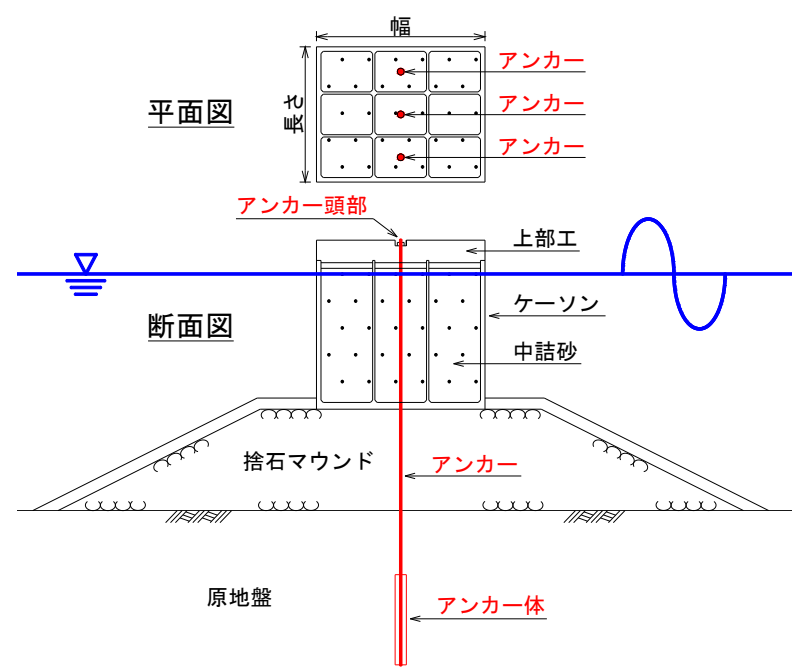

図-1 アンカーによる滑動防止対策工法概念

\section{3. 水理実験概要}

\section{（1）実験水路}

実験に使用した造波水路は, 長さ $50 \mathrm{~m}$, 幅 $0.6 \mathrm{~m}$, 高さ $1.2 \mathrm{~m}$ の二次元水路である. 造波機はピストン 形式であり, 周期 $0.5 \sim 50$ 秒, 最大波高 $50 \mathrm{~cm}$ の波を 造波可能である. 水路の一側面は透明なガラス面に なっているため, 実験の様子を目視で確認すること が可能である. 水路床は平坦とし, 造波機から $35 \mathrm{~m}$ の位置に捨石マウンドおよびケーソン模型を設置し た。また，越波による水位上昇を抑制するため，越 波水を造波機側へ還流するためのポンプをケーソン 港内側に設置した。

\section{（2）実験模型および波浪条件}

実験断面を図-2に示す。実験対象モデルはケーソ ン式防波堤とし, 模型縮尺は $1 / 30$ とした。ケーソン および捨石マウンドの形状は滑動安全率で決まるよ うに決定した。ケーソン模型は箱型のステンレス鋼 款(幅 $0.5 \mathrm{~m}$, 高さ $0.5 \mathrm{~m}$, 長さ $0.56 \mathrm{~m}$ )の中に砂を詰め て重量調整したものであり, 水中重量は $2.34 \mathrm{kN} / \mathrm{m}$ である．捨石マウンドおよび被覆石には，それぞれ 単粒度砕石 4 号 (粒径 20-30mm) および 1 号 (粒径 60$80 \mathrm{~mm})$ を使用した. アンカー工は, ケーソン中心に

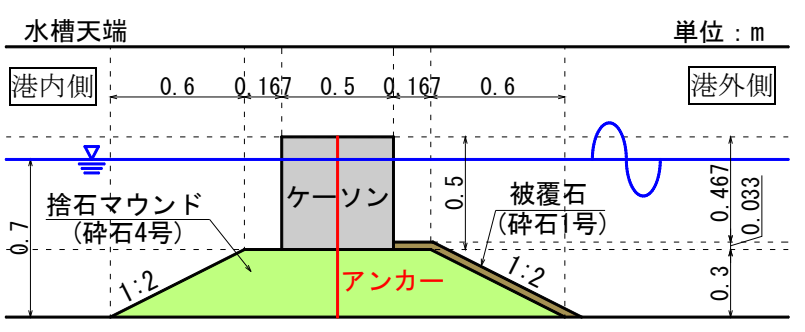

図-2 実験断面

表-1 波浪条件および防波堤諸元

\begin{tabular}{c|c|c|c|c}
\hline \multicolumn{2}{c|}{ 項 目 } & 単位 & $\begin{array}{c}\text { 実験 } \\
\text { モデル }\end{array}$ & $\begin{array}{c}\text { 現地 } \\
\text { スケール }\end{array}$ \\
\hline 波高 & & $\mathrm{m}$ & 0.325 & 9.75 \\
\hline 周期 & & $\mathrm{sec}$ & 2.14 & 11.7 \\
\hline ケーソン幅 & $\mathrm{B}$ & $\mathrm{m}$ & 0.5 & 15.0 \\
\hline ケーソン高さ & $\mathrm{H}$ & $\mathrm{m}$ & 0.5 & 15.0 \\
\hline ケーソン長さ & $\mathrm{L}$ & $\mathrm{m}$ & 0.56 & 16.8 \\
\hline 捨石マウンド高さ & $\mathrm{t}$ & $\mathrm{m}$ & 0.3 & 9.0 \\
\hline 水深 & $\mathrm{h}$ & $\mathrm{m}$ & 0.7 & 21.0 \\
\hline
\end{tabular}

おいてケーソン天端と捨石マウンド底部を鋼製ワイ ヤ(径 $1 \mathrm{~mm}$ )にて結束し固定する構造とした. 本実験 はアンカーによる補強効果を確認する基礎実験であ るため, アンカーは 1 本のみ配置し, 入射波は規則 波とした．規則波の波高および周期は，無対策の状 態でケーソンが滑動することを想定し, 滑動安全率 が 0.8 程度となる波高 $0.325 \mathrm{~m}$, 周期 $2.14 \mathrm{sec}$ とした. 表-1 に波浪条件および防波堤諸元を示す.

\section{（3）検討ケースおよび計測方法}

表-2 に検討ケースを示寸，検討ケースは，無対 策の場合(CASE1)とアンカーによる補強を行う場合 とし, 後者についてはアンカーの初期緊張力を 0.1 〜 $0.4 \mathrm{kN}$ まで $0.1 \mathrm{kN}$ ずつ変えて 4 ケース(CASE2〜5) 行い，実験は全部で 5 ケース実施した. CASE2〜 5 についてアンカー初期張力を現地スケールに換算す ると $2700 \sim 10800 \mathrm{kN}$ となり, アンカーとして F360TA(常時許容荷重 $915 \mathrm{kN}$ ) 使用する場合, ケーソン 1 函あたりに必要なアンカーは $3 \sim 12$ 本と なる。一方, 各ケースについて求めた滑動安全率は 0.84 1.15 となる. なお, ケーソンの滑動・転倒安 全率の算定 ${ }^{2)}$ は, 図-3 に示寸外力を想定し, 波力 算定式として合田式を用い, 摩擦係数を 0.6 と仮定 して行った.

表-2 検討ケース

\begin{tabular}{|c|c|c|c|c|c|}
\hline \multirow{3}{*}{ ケース } & \multicolumn{3}{|c|}{ アンカー } & \multirow{2}{*}{\multicolumn{2}{|c|}{ 安全率 }} \\
\hline & \multicolumn{2}{|c|}{ 初期張力 } & \multirow{2}{*}{$\begin{array}{c}\text { 必要本数 } \\
\text { (F360TA) } \\
\text { 現地 } \\
\text { モデル } \\
\text { (本) }\end{array}$} & & \\
\hline & $\begin{array}{c}\text { 実験 } \\
\text { モデル } \\
(\mathrm{kN})\end{array}$ & $\begin{array}{c}\text { 現地ス } \\
\text { ケール } \\
(\mathrm{kN})\end{array}$ & & 滑動 & 転倒 \\
\hline CASE1 & 0.0 & 0 & 0 & 0.84 & 1.25 \\
\hline CASE2 & 0.1 & 2700 & 3 & 0.92 & 1.38 \\
\hline CASE3 & 0.2 & 5400 & 6 & 1.00 & 1.51 \\
\hline CASE4 & 0.3 & 8100 & 9 & 1.07 & 1.63 \\
\hline CASE5 & 0.4 & 10800 & 12 & 1.15 & 1.76 \\
\hline
\end{tabular}




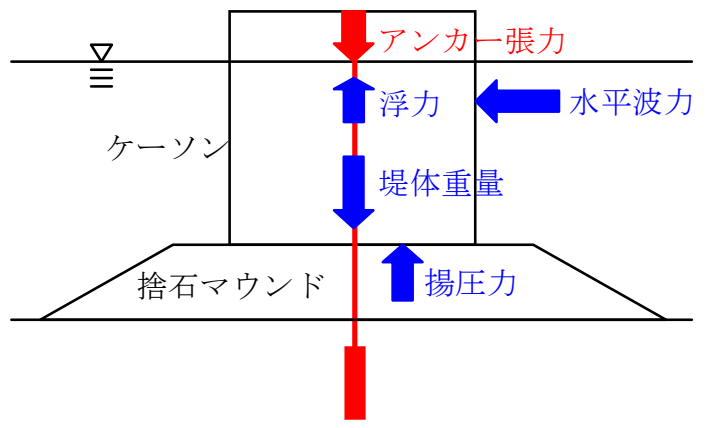

図-3 安全率算定モデル

計測器として波圧計，変位計および張力計を使用 し，ケーソン前面および底面に作用する波圧，ケー ソンの水平・鉛直変位, アンカーとして使用したワ イヤに作用する張力を計測した。また，波高計によ りケーソン付近の波高を計測した。図-4に計測器設 置位置を示す.

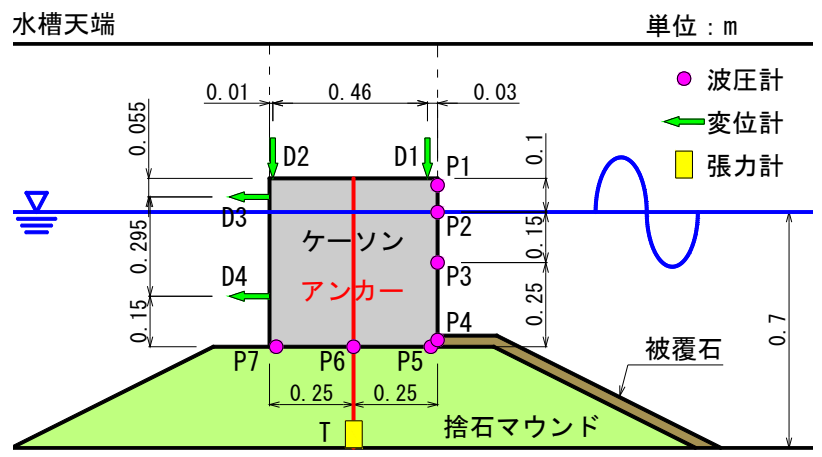

図-4 計測器設置位置

\section{4. 実験結果}

\section{（1）作用波力について}

図-5に，計測波圧から求めた水平波力および揚圧 力の時刻歴をCASE1およびCASE5について示す. 水平波力および揚圧力は，両ケースとも同様の波形 を示していることから，アンカーの有無や初期張力 の違いが波力に及ぼす影響は小さいと判断される. 波力の経時変化に着目すると，20秒付近まで振幅が 一定割合で増加し，その後 3,4 波は定常状態となる が，30秒付近から波力の振幅および平均值が増加し 約37秒の時点で波力がピークに達している．30秒付 近で波力の振幅が増加したのは，ケーソンで反射し た波を造波機で完全には吸収制御できなかったため と考えられる。一方，波力の平均值が増加したのは， 越波水量が還流ポンプの排水能力を超えたことによ り水位が $2 \mathrm{~cm}$ 程度上昇したためと推察される。

図-6に，37秒付近における水平波力および揚圧力 の最大值を全ケースについて示寸。図中には合田式 による值も併せて示している．水平波力，揚圧力と も各ケースの最大值に有意な差は認められない。揚 圧力は合田式と良い対応を示しているが，水平波力



(a) 水平波力

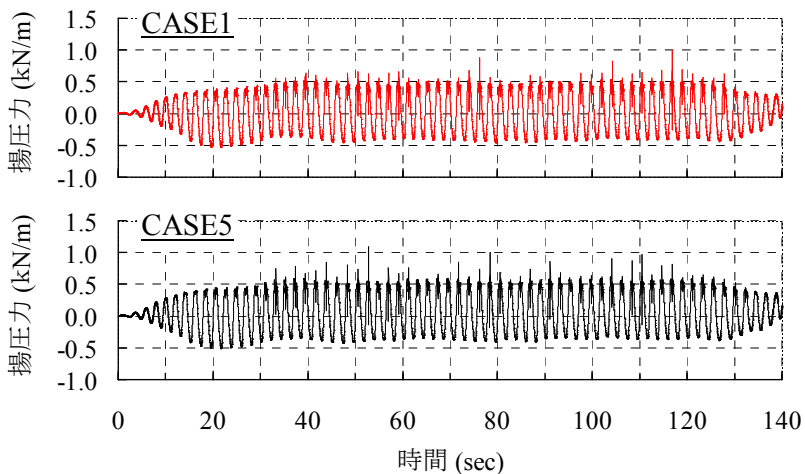

(b) 揚圧力

図-5 水平波力および揚圧力時刻歴

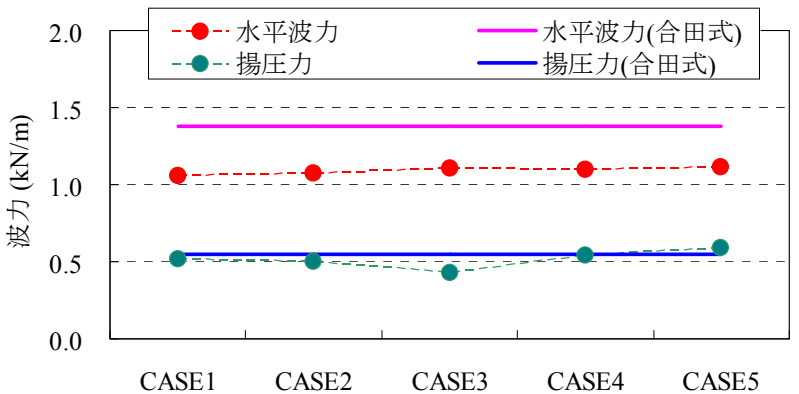

図-6 水平波力および揚圧力の最大值

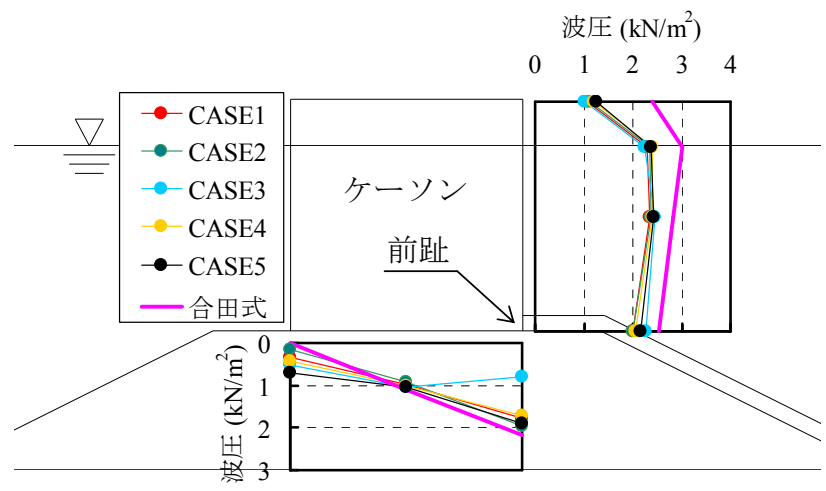

図-7 波力最大時の波圧分布

は合田式に対して2〜3割小さくなった.

水平波力最大時におけるケーソン前面および底面 に作用する波圧分布を図-7に示す。図中には合田式 
から算定した波圧分布も併せて示している。 CASE3ではケーソン前趾の底面波圧が小さな值を 示しているが，それ以外の波圧は各ケースとも同様 の分布形状を示している。CASE3でケーソン前趾 の底面波圧が小さくなったのは，波圧計の受圧面が 捨石マウンドの砕石によって塞がれてしまったため と考えられる。実際の值は，他のケースと同様に ケーソン前趾における前面波圧とほぼ等しくなると 考えられ，約 $2 \mathrm{kN} / \mathrm{m}^{2}$ であったと推測される。実験 による前面波圧分布は合田式と良く似た形状を示し ているが，その值は1〜5割小さい。この原因として 合田式が波圧を大きめに推定する傾向にあることが 挙げられる ${ }^{3)}$. また, 中田ら ${ }^{4)}$ にると低天端の場 合には合田式と比較して波力が小さくなることが指 摘されており，本実験のケーソンも天端高が低いた め(相対天端高0.31), 同様の現象が生じたと考えら れる。

\section{（2）ケーソンの変位特性}

計測変位から求めたケーソン中心の水平・鉛直変 位および回転角の時刻歴を図-8に示す。ただし, 水 平，鉛直変位はそれぞれ港内側および下向きを正と し，回転角はケーソンが港内側へ倒れる方向を正と している.なお，時刻歴波形にはノイズと思われる 高周波成分が多く含まれていたため，5Hzローパス フィルターによる平滑化処理を行った。 ケーソンは 主に2度大きく変位しており，1度目は8～21秒の間 (「変位段階 I」と定義)，2度目は28～40秒の間 (「変位段階 II」と定義)である.ケーソンの変位は, 変位段階 I では波力振幅の増加中に, 変位段階 II で は波力の振幅と平均值の増加中に生じており, 波力 が定常状態あるいはピークに達したときに変位が停 止する結果が示されている。このことは, 滑動後に ケーソンの安定性が向上していることを示唆してい る。宮田ら ${ }^{5)}$ によと, ケーソンは捨石マウンドの 表層砕石を引きずりながら変位することが指摘され ており，捨石マウンドの剛性や強度がケーソンの滑 動安定性に影響することを示唆している。このため, 本実験ではケーソンのロッキング運動にともなう捨 石マウンドの締固めや，砕石がケーソンに引きずら れて捨石マウンド表層の一部が密になることで捨石 マウンドの剛性や強度が増加し, ケーソンの滑動安 定性が向上していたと推察される。変位段階 I と変 位段階 IIのケーソンの水平変位を比較すると, 後者 の方が増加量が大きくなっている.これは, 変位段 階IIでは波力が大きいこと，水位上昇によってケー ソンの浮力が増加したことによると考えられる。40 秒以降についてみると, CASE1およびCASE2にお ける水平変位は概水一定值に収束しているが, CASE3〜 5ではわずかに減少する傾向を示している ケーソンの鉛直変位時刻歴によると, 波力が作用 し始めてからピークに達する40秒付近まで，概ね一 定の傾きで増加しており, 水平変位とやや異なる挙 動を示していることから，ケーソンの沈下はいわゆ

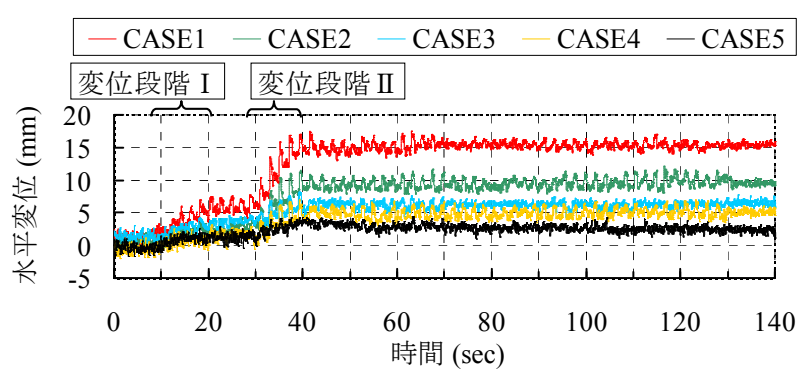

(a) 水平変位

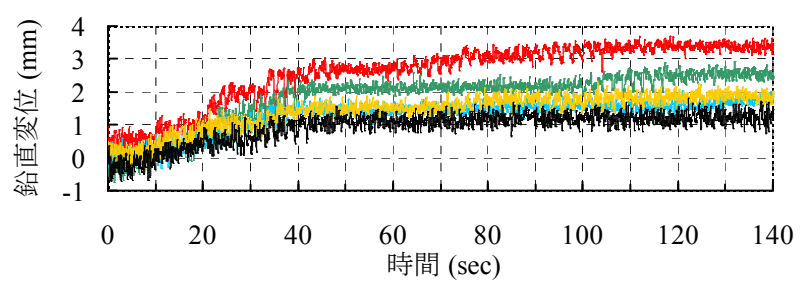

(b) 鉛直変位

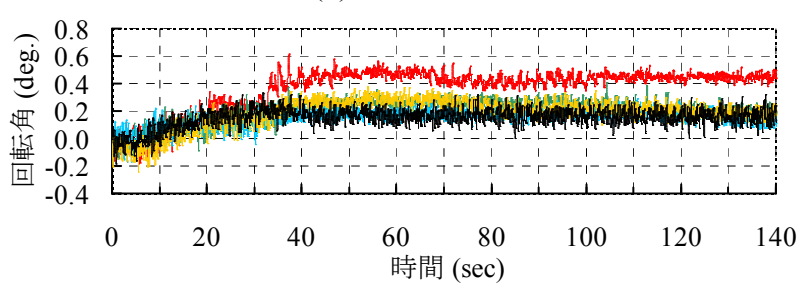

(c) 回転角

図-8 ケーソンの水平・鉛直変位および回転角の時刻歴
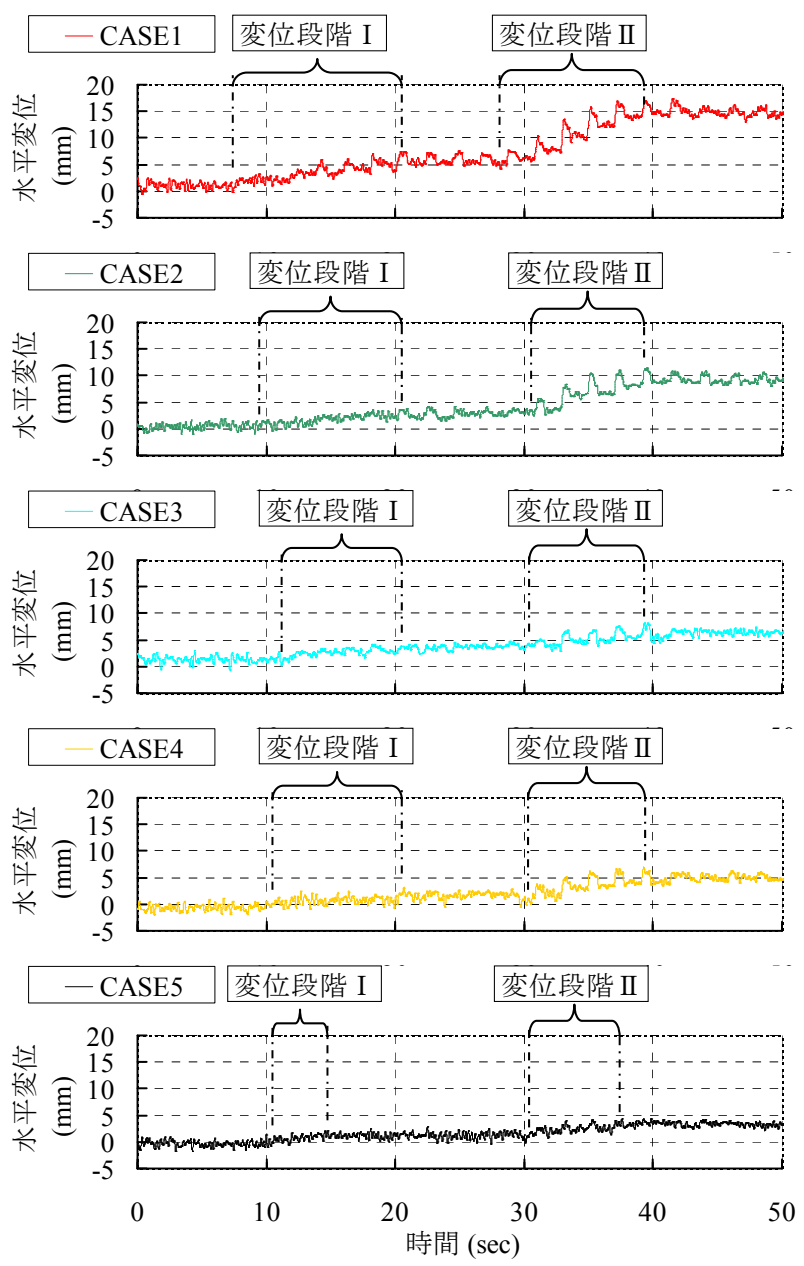

図-9 ケーソン水平変位時刻歴の各ケースの比較 
る支持力破壊ではなく, ケーソンのロッキング運動 に起因する捨石マウンドの締固めが主な原因である と推察される. 回転角も概衩一定の傾きで増加して おりケーソンは港内側へ倒れるように変位している が，その值は最大でも0.6度と小さいことからケー ソンの変位モードは滑動が卓越していたと判断され る. 40秒を過ぎてから, 鉛直変位はやや増加傾向に あり, その増加量はアンカー張力が大きいケースほ ど小さくなる傾向を示している．回転角はわずかに 減少傾向を示しているがその值は小さい.

ケーソンの変位時の挙動を各ケースで比較するた め, ケーソン水平変位時刻歴の各ケースの比較を 図-9に示寸，各変位段階における変位発生時刻は, 無対策の場合(CASE1) と比べてアンカーありの場合 (CASE2〜5)では2,3秒遅れており，アンカーによる 補強でケーソンの滑動抵抗力が増加したと判断され る.また, CASE5では変位終了時刻が他のケース と比較して大幅に早くなっており, アンカー張力が 大きい場合, 滑動抵抗力がさらに増加寸ることを示 している. 各変位段階における変位増加量や変位継 続時間は, アンカー初期張力が大きいケースほど小 さくなる傾向が認められることから，アンカーによ る補強でケーソンの滑動量が抑えられ, かつ初期張 力が大きいほどその効果も大きくなることがわかる ケーソン中心の水平および鉛直変位の最大值を 図-10に示す. ケーソン水平変位は, アンカー初期 張力が大きいケースほど小さくなっており，アン カーによるケーソンの滑動防止対策が有効である結 果が示されている. 図-10をアンカー初期張力と最 大変位の関係と見た場合, 初期張力が $0.1 \mathrm{kN}$ 増加し たときのケーソン水平変位の減少量が最も大きいの はCASE1 とCASE2の間(約6mm)であることから，初 期張力が小さい場合でもアンカーによる補強がケー ソンの滑動防止対策として有効であると考えられる。 ケーソンの鉛直変位もアンカー初期張力が大きい ケースほど小さくなっている。これは, アンカー初 期張力により捨石マウンドの拘束圧が増えて剛性が 増した結果, 締固めによる捨石マウンドの沈下が抑 制されたためと推察される。

\section{（3）アンカーの張力特性}

アンカー張力の時刻歴を図-11に示寸. 張力は 8 秒 付近から減少し始め, 時間を追うごとに減少割合が 低下寸る傾向を示している. 一方, 波力 1 波ごとの 挙動をみると, ケーソンの変位振幅に対応してアン カー張力も増減しており, この傾向は波力が大きく なる30〜40秒で顕著である. このことは, アンカー がケーソンの滑動抑制に寄与していることを示唆し ている.

アンカー張力の減少原因を調べるため, 図-12に ケーソン鉛直変位とアンカー張力低減量の履歴を示 す。同図によると, CASE4およびCASE5において 両者の間に線形的な関係が認められる.CASE2お よびCASE3についても張力低減量がそれぞれ初期 張力の約半分の $0.05 \mathrm{kN}$ よび $0.1 \mathrm{kN}$ なるまでは線

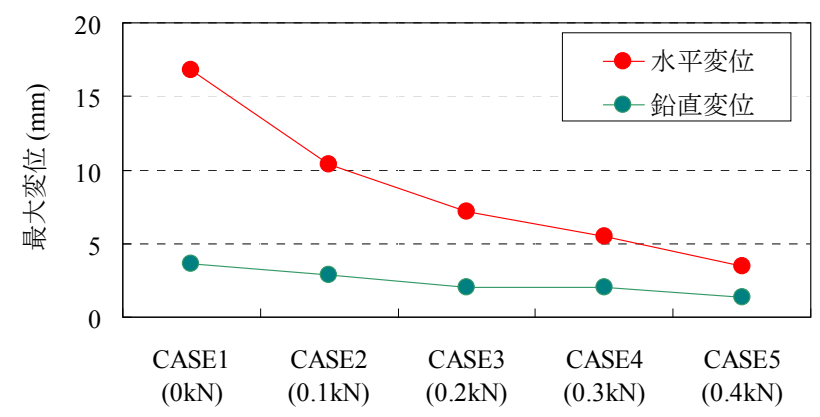

注) 括弧内の数字は, アンカー初期張力の值 図-10 ケーソンの水平および鉛直変位の最大值

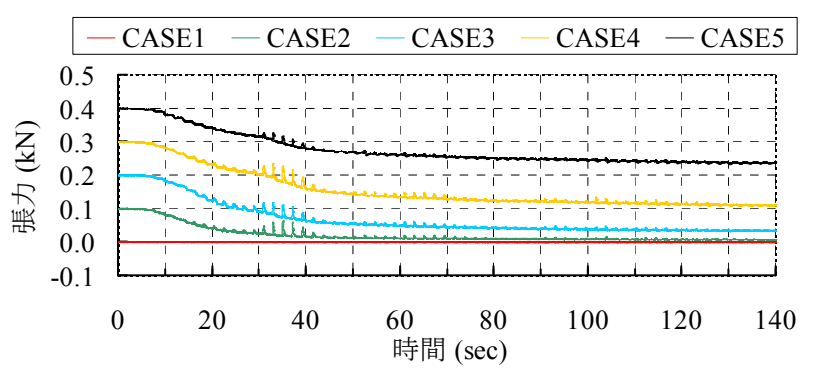

図-11 アンカー張力時刻歷

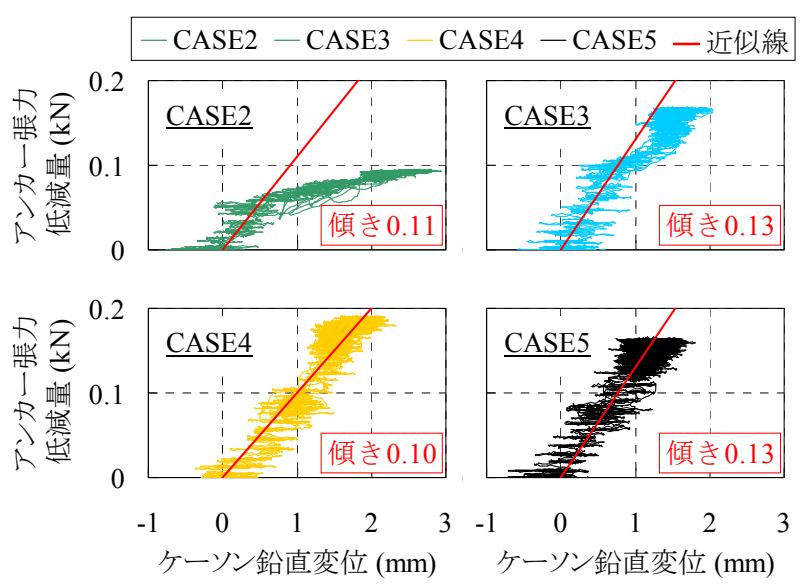

図-12 ケーソン鉛直変位とアンカー張力低減量の履歷

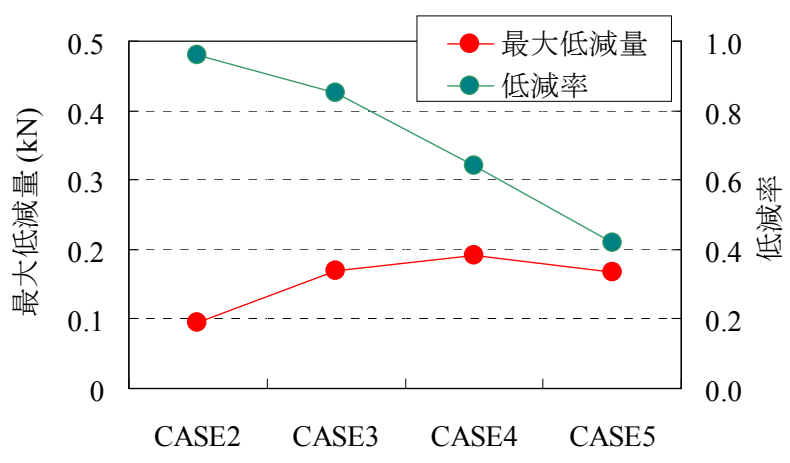

図-13 アンカー張力の低減量最大值および低減率

形関係が認められる。このことから，アンカー張力 の減少原因は, 主にケーソンの沈下であると判断さ れる. 上記の線形関係について図-12中に近似線を 示すが，各ケースの近似線の傾きは $0.10 \sim 0.13$ の範 囲内にありお互いに近い值を示している。このこと 
は, ケーソン鉛直変位とアンカー張力低減量の関係 が，アンカー初期張力とは関係なしに堤体条件等そ の他の条件により一義的に決まる可能性があること を示している。CASE2およびCASE3では，アン カー張力減少量が初期張力の約半分に達した後に増 加しにくくなる傾向を示している.これはケーソン 水平変位が急増しアンカーが緩みにくくなったため と推察される。

アンカー張力の低減量最大值および低減率(低減 量最大值 / 初期張力)を図-13に示す. 張力の低減率 は，初期張力が大きいケースほど小さくなる傾向を 示している。一方, 張力の最大低減量をみると, CASE2では実験後に張力を完全に失ったため最大 低減量は初期張力と同じ $0.1 \mathrm{kN}$ とっているが，実 験後に張力が残留したCASE3〜5では各ケースとも 概ね同じ約 $0.2 \mathrm{kN}$ とった。これは，前述したよう に，アンカー初期張力が大きい場合にはケーソンの 沈下量が低減されることで張力の低減量も小さくな り，初期張力が小さい場合にもケーソンの沈下量は 増加するが水平変位量も大きくなるためアンカーは それほど緩まずに張力の低減量が小さくなり，結果 的にCASE3〜 5で張力の低減量が同じになったと推 察される。

\section{5. まとめ}

二次元造波水路による水理実験を実施し，グラウ ンドアンカーによるケーソン式防波堤の滑動防止対 策効果に関する基礎的な検討を行った結果，以下の 知見が得られた。

(1)ケーソンの水平変位最大值は, アンカーの初 期張力が大きいケースほど小さくなっており, 鉛直変位最大值についても同様の結果が示され た。また，ケーソンの変位開始時刻は，無対策 の場合(CASE1) と比べてアンカーありの場合 (CASE2〜 5)で 2,3 秒遅れており, さらに初期張 力が最も大きい CASE5 では滑動停止時刻が他 のケースと比較して大幅に早くなっていた．以 上のことから，アンカーによるケーソンの滑動 防止対策が有効であり, アンカーの初期張力が 大きいほど対策効果が大きくなることを確認し た.

(2)ケーソンは波力の振幅や平均值の増加中に大 きく水平変位しており, 波力が定常状態あるい はピークに達したときに変位が停止する結果が 示されている．このことは，滑動後にケーソン の安定性が向上していることを示唆しており， これはケーソンのロッキング運動にともなら捨 石マウンドの締固めや, 砕石がケーソンに引き
ずられて捨石マウンド表層の一部が密になるこ とで捨石マウンドの剛性や強度が増加したため と推察される。

(3)アンカー初期張力が大きいケースほどケーソ ンの鉛直変位最大值が小さくなっているのは, 初期張力により捨石マウンドの拘束圧が増えて 剛性が増した結果, 締固めによる捨石マウンド の沈下が抑制されたためと推察される.

(4)アンカー張力は波力作用中に減少しており, 時間を追うごとに減少割合が低下する傾向を示 している.アンカー張力の減少量はケーソンの 鉛直変位と相関性があることから, 張力の減少 原因は主にケーソンの沈下に依るものと判断さ れる。

(5)アンカー張力の最大低減量が CASE3〜 5 で概 ね同じ值になったのは，アンカー初期張力が大 きい場合にはケーソンの沈下量が低減されるこ とで張力の低減量も小さくなり，初期張力が小 さい場合にもケーソンの沈下量は大きいものの 水平変位も大きいためアンカーがそれほど緩ま ずに張力の低減量が小さくなったことによると 推察される.

(6)ケーソンに作用する水平波力および揚圧力は, 各ケースとも同様の時刻歴波形を示しており, 最大值に有意な差は認められないことから，ア ンカーの有無や初期張力の違いが波力に及ぼす 影響は小さいと判断される.

謝辞：本研究は早稲田大学, 五洋建設(株), 東亜建 設工業(株), 東洋建設(株)および(株)エスイーの5機 関による産学共同研究の一部として実施したもので す。実験の計画, 実施および評価にあたり, 東覀建 設工業(株)の永友久信氏，青野利夫氏，東洋建設 (株)の前田涼一氏には, 多大なご協力をいただきま した。ここに記して御礼申し上げます。

\section{参考文献}

1) 土木学会海岸工学委員会編 : 地球温暖化の沿岸影響, 土木学会, 1994.

2) (社) 日本港湾協会 : 港湾の施設の技術上の基準 - 同解 説, 1999.

3) 合田良實：耐波工学，鹿島出版会，p.110, 2008.

4) 中田邦夫, 寺内潔, 西田仁志, 梅木功: 低天端混成堤 の諸特性について, 海岸工学論文集, 第 31 巻, pp.543-536, 1984.

5) 宮田正史，吉田誠，安野浩一朗，三好俊康，三藤正明， 熊谷健蔵：偶発波浪荷重を受けるケーソン式防波堤の 大変形メカニズムに関する実験的研究, 土木学会論文 集 B2（海岸工学）, Vol.65, No.1, pp.886-890, 2009. 